\title{
Prognostic significance of DNA ploidy in lung cancer
}

\section{Akciğer kanserlerinde DNA ploidinin prognostik önemi}

\author{
$\underline{\text { Hüseyin Çakmak }}^{1}$, Arif Osman Tokat ${ }^{2}$, Nalan Açıkgöz Akgün ${ }^{3}$, Hadi Akay ${ }^{4}$, Olgun Arıbaş ${ }^{5}$ \\ ${ }^{1}$ Medical Park Ankara Hastanesi Göğüs Cerrahisi Bölümü, Ankara \\ ${ }^{2}$ Yozgat Bozok Üniversitesi Tıp Fakültesi Gögüs Cerrahisi Anabilim Dalı, Yozgat \\ ${ }^{3}$ Ankara Üniversitesi Tıp Fakültesi, Tıbbi Onkoloji Anabilim Dalı, Ankara \\ ${ }^{4}$ Ankara Üniversitesi Tıp Fakültesi Göğüs Cerrahisi Anabilim Dalı, Ankara (2006'da Vefat) \\ ${ }^{5}$ Gazi Üniversitesi Tıp Fakültesi Göğüs Cerrahisi Anabilim Dalı, Ankara
}

Dergiye Ulaşma Tarihi: 08.05.2018 Dergiye Kabul Tarihi: 13.06.2018 Doi: 10.5505/aot.2018.74755

\section{ÖZET}

GİRIŞ ve AMAÇ: Akciğer kanserleri tüm dünyada oldukça yaygın olarak görülen ve mortalitesi yüksek olan neoplazmlardır. Akciğer kanserlerinde, önceden bilinen prognostik faktörlerin, tümörün klinik seyrindeki ve prognozundaki değişkenliği yansıtmada yetersiz kaldığı bilinmektedir. Çalışmamızda küçük hücreli dışı akciğer kanserlerinde opere edilen hastaların tümör DNA ploidi tipinin prognoza olan etkisinin belirlenmesi amaçlanmıştır.

YÖNTEM ve GEREÇLER: Küçük hücreli dış1 akciğer kanserli 35 hasta opere edildi. Taze tümör dokusundan flow sitometrik inceleme yapılarak tümör DNA ploidi tipi ile proliferasyon aktivitesi(S fazı) belirlendi. $\mathrm{Bu}$ veriler hastaların TNM evresi, histopatolojik tipi ve takip süresi içindeki son durumu ile karşılaştırıldı. BULGULAR: DNA ploidi analizi sonucunda 35 olgunun 16'sında(\%45,8) anöploidi ve 19'unda da $(\% 54,2)$ diploidi saptandı. Ploidi tipi ve S fazı ile histopatolojik tip, TNM evresi ve klinik son durum karşılaştırıldığında özellikle anöploid DNA’lı ve/veya $\mathrm{S}$ fazı yüksek olan olgularda nüks veya metastazlar gözlendi. $(p<0,05)$ TARTIŞMA ve SONUÇ: Küçük hücreli dışı akciğer kanserlerinde, tümör DNA ploidi tipi ile $S$ fazı, tümörün biyolojik davranışını yansıtan ve prognoza etkili faktörler olarak değerlendirildi.

Anahtar Kelimeler: DNA ploidi, Akciğer kanseri, flow sitometri

ABSTRACT
INTRODUCTION: Lung cancers widespread throughout the world. Previously known prognostic factors in
lung cancers are inadequate in reflecting a change in prognosis and clinical course of the tumour. The aim of this
study was to determine the effect on prognosis of tumour DNA ploidy type in are neoplasms with high mortality
rates that are extremely patients operated on for non small cell lung cancer.
METHODS: A total of 35 patients were operated on because of non small cell lung cancer. Using flow
cytometric examination of fresh tumour tissue, the proliferation activity (S phase) was determined together with
tumour DNA ploidy type. These data were compared with the TNM grade, the histopathological type and the last
status of patients within the follow-up period.
RESULTS: As a result of DNA ploidy analysis, aneuploidy was determined in 16 (45.8\%) patients and diploidy
in 19 (54.2\%). When the ploidy type and S phase were compared with histopathological type, TNM grade and
last clinical status, recurrence and metastasis were observed at a significantly higher rate in cases with anaploidy
DNA and/or high S phase (p<0.05)
DISCUSSION and CONCLUSION: Tumour DNA ploidy type and S phase can be evaluated as effective
prognostic factors reflecting the biological behaviour of the tumour in non small cell lung cancers.
Keywords: DNA ploidy, Lung Cancer, flow cytometry




\section{GİRIS}

Akciğer kanserleri tüm dünyada oldukça yaygın olarak görülen ve mortalitesi yüksek olan neoplazmlardır (15). Ülkemizde özellikle erkeklerde kansere bağlı ölümlerde ilk sırada yer alan akciğer kanserlerinde her geçen y1l belirgin artış olmaktadır (7). Akciğer kanseri tanıs1 alanların sadece \%10' u 5 yıl yaşayabilmektedir. Çünkü tanı sırasında çoğu inoperabil olarak tespit edilmektedir. Erken evre akciğer kanserinde bile, cerrahi rezeksiyon sonrasındaki 5 yıl içinde nüks oranı \%20-30 olarak bildirilmektedir (15).

Akciğer kanserlerinde, önceden bilinen prognostik faktörlerin, tümörün klinik seyrindeki ve prognozundaki değişkenliği yansıtmada yetersiz kaldığı bilinmektedir. Bu nedenle tümörün biyolojik davranışını ve genetik yapısını belirleyen yeni prognostik belirleyicilere gereksinim duyulmaktadır. $\mathrm{Bu}$ konuda yapilan incelemeler sonucunda da akciğer kanserlerinde, tümör DNA ploidisinin, oldukça değerli prognoz belirleyici bir faktör olduğu anlaşılmıştır.

Çalışmamızda akciğer kanserlerinde flow sitometri tekniği ile belirlenen tümör DNA ploidisinin prognoza olan etkisi araştırılmıştır. Böylece tümör ploidisi ile prognoz arasında belirgin bir ilişki saptanması durumunda, nüks ve/veya metastaz riski yüksek olan hastalar önceden tahmin edilebilecektir.

\section{MATERYAL ve METOT}

Çalışma, Ankara Üniversitesi Tıp Fakültesi Göğüs Cerrahisi Anabilim Dalında Kasım 1996 ve Aralık 1997 tarihleri arasında akciğer kanseri tanısı ile opere edilen 35 olguda gerçekleştirildi. Cerrahi olarak çıkarılan tümörden taze doku örnekleri alınıp, flow sitometrik inceleme için Tıbbi Onkoloji flow sitometri laboratuvarına gönderildi.

Çalışma kapsamındaki 35 olgunun 5'i (\%14.2) kadın ve 30'u(\%85.8) erkek idi. Olguların yaş sınırı 46-70 ve yaş ortalaması da 58.6 olarak saptandi. TNM evrelendirme sistemine göre 35 olgunun 7'si(\%20) evre I, 15'i $(\% 42.8)$ evre II, 10 'u(\%28.5) evre IIIa ve 3'ü de (\%8.6) evre IIIb olarak belirlendi. Olguların 24 'ünde(\%68,5) histopatolojik tip yassı hücreli karsinoma ve kalan 11 'inde de adenokarsinom olarak belirlendi. Olgulara uygulanan operasyonun tipi ise Tablo 1' de belirtilmiştir.

\section{İstatistiksel Analiz}

Çalışmaya ait tüm istatistiksel analizlerde, SPSS- IBBM 24.0 versiyonu istatistik analiz programı ile ki-kare testi kullanıldı. $\mathrm{P}<0,05$ olan değerler istatistiksel olarak anlamlı kabul edildi.

\section{BULGULAR}

Olgulardan 19'unda $(\% 54,2)$ diploid DNA ve 16'sında $(\% 45,8)$ anöploid DNA saptand1. Diploid DNA'l1 19 olgunun 15'inde(\%78,9) histopatolojik tip yassı hücreli karsinoma ve 4'ünde de $(\% 21,1)$ adenokarsinom idi. Anöploid DNA'lı 16 olgunun ise 9'u(\%56,2) yassı hücreli karsinom ve kalan 7'si $(\% 43,8)$ ise adenokarsinom idi. $S$ faz1 ise \%0,3-18,7 arasında olup ortalama $S$ fazı değeri \%6,38 olarak belirlendi. Tablo 2'de DNA ploidinin TNM evrelerine göre dağılımı ile Tablo 3'de S fazı değerlerinin histopatolojik tip ve ploidi tiplerine göre dağılımı gösterilmiştir.

Çalışmaya alınan olgular operasyon tarihi başlangıç olarak alınıp, 5-20 ay (ortalama 12,6 ay) süre ile takibe alındı. Bu takip süresi boyunca 24 hastada nüks veya metastaz lehine herhangi bir gelişme gözlenmedi. Bu 24 olgunun, 15 tanesi diploid DNA'ya sahipti ve bunların ortalama takip süresi 12,4 ay olarak belirlendi. Diploid DNA'l1 olan bu 15 olgunun 4'ü evre I, 5'i evre II ve 3'ü de evre IIIa olmak üzere 12'si yass1 hücreli karsinomlu olgular idi. Kalan 9 normal kontrol olgusu da anöploid DNA'lı olgular idi. Bunlarında ortalama takip süresi 14,2 ay olarak belirlendi. Anöploid DNA'lı bu 9 olgunun, 1'i evre I, 4'ü evre II ve 1 'i de evre IIIa olmak üzere 6's1 yassı hücreli karsinomlu olgular idi. 
Kalan 3 olgu ise 1'i evre I, 1'i evre IIIa ve 1'i de evre IIIb adenokarsinomlu olgular idi. Çalışma serisinde yer alan 1'i anöploid, 2'si de diploid DNA'l1 3 olgu takip dönemi içinde kontrole gelmemiş ve kendilerine ulaşılamadığ 1 için son durumları hakkında bilgi alınamamıștır. Bu olgulardan diploid DNA'lı olanların 1'i evre I, diğeri de evre IIIa ve anöploid DNA'lı olan 3.olgu ise evre IIIa yass1 hücreli karsinom nedeniyle opere edilen olgulard. Takip döneminde kalan diğer 8 olguda ise, diploid evre IIIa yassı hücreli 1 olguda postoperatif 8 . ayda miyokard infarktüsü nedeniyle ölüm meydana geldi. Yine diploid, evre II adenokarsinomlu 1 olguda postoperatif 5.ayda intrakranial metastaz saptand1. Anöploid, evre IIIa yass1 hücre karsinomlu 1 olguda postoperatif 13. ayda kemik metastazı belirlendi. Bunun dışında anöploid, evre II yass1 hücre karsinomlu 1 olguda postoperatif 10. ayda karşı akciğerde metastaz saptanıp, anöploid, evre IIIb adenokarsinomlu 1 olguda da kemik metastazı saptandı. Kemik metastazı saptanan olgu, daha sonra kemoterapi sirasinda öldü. Yine anöploid, evre II, evre IIIa ve IIIb olan 3 adenokarsinom olgusunda, takip döneminin 12 ve 13. aylarında daha önceki primer karsinomun olduğu tarafda nüks gözlendi.

Çalışma serisi içindeki toplam 19 diploid DNA'l1 olgudan sadece1 'inde $(\% 5,2)$ takip dönemi içinde 5. ayda intrakranial metastaz saptandı. $\mathrm{Bu}$ olgunun S-fazı, \%18 olarak oldukça yüksek bulundu. Buna karş1lık toplam 16 anöploid olgudan 6'sinda $(\% 37,5)$ metastaz veya nüks saptandi. $\mathrm{Bu}$ gruptaki olguların ortalama S-fazı, \%7,06 belirlendi. Tüm seriye ait ortalama S-fazı, \%6,38 belirlenmişti. Görüldüğü gibi anöploid DNA'lı akciğer kanserli olguların operasyon sonrası takiplerinde nüks ve metastaz oranları diploid
DNA'lı olgulara göre belirgin şekilde yüksek bulundu $(\mathrm{p}<0,05)$. Bir diğer önemli nokta da, postoperatif 5.ayda intrakranial metastaz ile en erken metastaz saptanan olgunun diploid olmasına karşılık, S-fazının \%18 gibi çok yüksek bir değerde olmasıdır. Çalışmadaki toplam 35 olgunun 11'i $(\% 31,5)$ adenokarsinomlu idi ve 7 'sinde $(\% 63,6)$ anöploidi saptanmıştı. $\mathrm{Bu} 7$ anöploid olgunun da 4 tanesinde (\%57) nüks veya metastaza rastlandı. Buna karşı1ık yassı hücreli karsinomlu 24 olgudan (\%68,5), 9'unda $(\% 37,5)$ anöploidiye rastlanılmış ve bunlarında sadece 2'sinde $(\% 22,2)$ metastaz saptanmıştır. Buradan anöploidi sıklığı ile nüks veya metastaz sıklığının adenokarsinomdan yana daha fazla olduğu görülmektedir $(\mathrm{p}<0,05)$. Çalışmadan çıkan bir diğer sonuç da hem anöploid hem de diploid olguların en çok evre II'de $(\% 37,5-\%, 47,3)$ ikinci siklıkta da evreIIIa'da $\quad(\% 31,2-\% 26,3) \quad$ bulunmasidır $(\mathrm{p}>0,05)$.

Tablo 1: Uygulanan operasyon tiplerine göre olguların dağılımı

\begin{tabular}{|l|l|}
\hline$\underline{\text { OPERASYON TIPI }}$ & $\underline{\underline{\text { OLGU }}}$ \\
\hline Sağ üst lobektomi & 9 \\
\hline Sol üst lobektomi & 6 \\
\hline Sağ alt lobektomi & 4 \\
\hline Sol alt lobektomi & 3 \\
\hline Sağ orta-alt bilobektomi & 1 \\
\hline Sağ üst lobek.+ toraks duvarı rez & 1 \\
\hline Sol pnömonektomi & 8 \\
\hline
\end{tabular}


Tablo 2: DNA ploidi analizinde olguların TNM evrelerine göre dağılımı

\begin{tabular}{|c|c|c|c|c|}
\cline { 2 - 5 } \multicolumn{1}{c|}{} & EVRE I & EVRE II & EVRE IIIa & EVRE IIIb \\
\hline DİPLOİDI & $5(\% 26,3)$ & $9(\% 47,3)$ & $5(\% 26,3)$ & 0 \\
\hline ANOPLOİİ & $2(\% 12,5)$ & $6(\% 37,5)$ & $5(\% 31,2)$ & $3(\% 18,7)$ \\
\hline
\end{tabular}

Tablo 3: Olguların S fazı değerlerinin, histopatolojik tip ve ploidi tiplerine göre dağılımı

\begin{tabular}{|c|c|c|c|c|}
\cline { 2 - 5 } \multicolumn{1}{c|}{} & \multicolumn{2}{c|}{ YASSI HÜCRELI CA } & \multicolumn{2}{c|}{ ADENOCA } \\
\hline S Fazı (\%) & Diploid & Anöploid & Diploid & Anöploid \\
\hline $0-6$ & 12 & 0 & 3 & 3 \\
\hline $6-10$ & 1 & 5 & 0 & 4 \\
\hline$>10$ & 2 & 4 & 1 & 0 \\
\hline
\end{tabular}

\section{TARTIŞMA}

Küçük hücreli dış1 akciğer kanserlerinde (KHDAK), DNA ploidi tipinin prognoz ile ilişkisinin olup olmadığını belirlemek için çok sayıda çalışma yapılmış ancak bunların birçoğunda çelişkili sonuçlar alınmıştır $(3,4)$. Anormal ploidi yapısına sahip tümörlerin genel olarak daha kötü bir prognoz içerdiği düşüncesi öne sürülmektedir. Fakat buna tamamen karşı çıkan veya bunun yetersiz olduğunu, ploidi anormalliği yanında diğer bazı faktörlerin de prognoza etkili olduğunu öne süren çalışmalar vardır. Gerek teknik üzerinde tam bir standardizasyonun oturmamas1 ve gerekse tümör heterojenitesi nedeniyle DNA ploidi tipinin prognoza olan etkisi üzerindeki tartışmalar halen devam etmektedir $(6,8,9)$.

KHDAK'lerinde DNA ploidi üzerine yapılan çalışmalarda \%45-96 oranında anöploidi saptanmıştır. Ancak elde edilen bu oranlar ve çalışma sonuçları üzerinde tam bir uyum yoktur. Çünkü yapılan çalışmaların çoğunda DNA ploidi anormalliğinin, prognoz açısından hangi histolojik tip ve evre için değerli olduğu ve flow sitometrik incelemede hangi örnek alma tekniğinin daha güvenilir olduğu konusunda anlaşmazlık vardır $(2,3,5,11,14,17)$.

Çalışmamızda da KHDAK'li olgular, DNA ploidi analizi ve prognozla olan ilişkisi yönünden incelendi. Yassı hücre karsinomlu 24 olgu ve adenokarsinomlu 11 olgu olmak üzere toplam 35 olgunun 16 'sinda( $\% 45,8)$ anöploidi ve 19 'unda da $(\% 54,2)$ diploidi saptandı. Elde ettiğimiz anöploidi oranı literatürde bildirilen oranlar ile uyumlu bulundu $(2,5,6,16,20)$.

Bunn (1) adlı araştırıcı, KHDAK'lerinde taze tümör dokusundan DNA ploidi analizi yaptığında $\% 83$ oranında anöploidi tespit etmiş, ancak çalışma sonunda DNA ploidi ve $S$ fazı ile yaşam süresi arasında herhangi bir ilişki belirleyememiştir.

Buna karşılık Volm (19) ve arkadaşları, KHDAK'lerinde taze tümör dokusu kullanarak yaptıkları çalışmada, \%83 oranında anöploidi tespit etmişler ve anöploid DNA'lı ve $S$ fazı \%9-16 arasinda olan olguların diploid DNA'11 olgulara göre belirgin şekilde daha az yaşadığını belirlemişlerdir. Çalışma sonucunda $\mathrm{da}$, anöploidi ile $\mathrm{S}$ fazının prognoz açısından önemli belirleyiciler olduğunu bildirmişlerdir.

Hedley'in(21) 1983 yllında parafin dokuda DNA ploidi analiz tekniğini tanımlaması ile akciğer kanserlerinde de bu yöntem oldukça yaygın olarak kullanılmaya başlanmıştır. Zimmerman (20), bu yöntemi kullanarak yaptığı çalışmasında, KHDAK'li olguların \%45'inde anöploidi, \%55'inde diploidi saptamış ve çalışma sonucunda DNA ploidinin, yaş, cinsiyet, operasyon tipi, tümör 
histolojisi ve TNM evresinden bağımsız bir prognoz belirleyici olduğunu ileri sürmüştür.

Çalışmamızdaki 16 anöploid olgunun, 9'u yassi hücre karsinomlu ve 7'si de adenokarsinomlu olgular idi. Bunlarında 2'si evre I, 6's1 evre II, 5'i evre IIIa ve 3'ü de evre IIIb olarak belirlenmiştir. Zimmerman (20) tarafindan anöploidinin TNM evresinden bağımsız bir prognostik faktör olduğu belirtilmesine karşılık çalışma serimizdeki anöploid olgular, en sik evre II'de ve evre IIIa'da saptanmıştır. Anöploidi ve diploidi oranları serimizle aynı olan Zimmerman'ın çalışması retrospektif bir çalışmadır ve 100 olgu üzerinde parafin doku örnekleri ile gerçekleştirilmiştir. Ancak serimizdeki olgu sayısı hem daha az, hem de evre ve histolojik tip açısından homojen dağılım söz konusu değildir.

Danesi (5) adlı araştırıcı, ise yine aynı yöntemi kullanarak yaptığ 1 çalışmada \%96 ile literatürde bildirilen en yüksek anöploidi oranına ulaşmıştır. Bu yüksek oran tümör dokusundan sistematik olarak birçok örnek alma sonucu multiklonalitenin saptanması ile açıklanmaktadır. Danesi'ye göre, tümörden tek örnek alınarak yapılan ploidi analizi, tümörün tamamının klonal yapısını yansitmamaktadır. Bu nedenle gerçekte anöploid olan bir tümör diploid olarak değerlendirilebilir. Eğer DNA histogramında 1'den fazla anöploid pik varsa multiklonalite veya intratümöral heterojeniteden bahsedilir ve böyle tümörlerin klinik seyri çok kötü olmaktadır. Çalışmanın sonunda DNA ploidinin, tek başına olmasa bile prognoz açısından önemli bir belirleyici olduğu kabul edilmektedir.

Çalışmamızda operasyon ile çıkarılan tümörden, farklı yerlerden ve çok sayıda taze doku örneği alınarak flow sitometrik inceleme yapıldı. Alınan örneklerde nekrotik doku bulunmamasına özen gösterildi. Nitekim flow sitometri ile elde edilen DNA histogramların kalitesini yansitan CV ortalamasi 4,82 değerinde saptandı. Ancak literatürde anöploid olgularda \%50'ye kadar varan oranlarda bildirilen ve intratümöral heterojeniteyi yansitan multiploidi veya multiklonaliteye çalışmamızdaki olguların hiçbirisinde rastlanmamıştır.

Ten Velde (18) ve arkadaşları ise, daha önceki çalışmaların sonuçlarından farklı olarak DNA ploidinin yaşam süresi ile herhangi bir ilgisinin olmadığını belirtmişlerdir. Fakat Volm'un çalışması ile uyumlu olarak yükssek $\mathrm{S}$ fazının, kötü prognoz ile ilişkili olduğunu ileri sürmüşlerdir.

Granone'nin (8) çalışmasındaki sonuçlar da, Volm ve Ten Velde'nin sonuçları ile uyumlu bulunarak ploidi den ziyade $S$ fazının prognostik öneminin olduğu belirtilmektedir.

Filderman (6) tarafindan evre I KHDAK'lerinde, DNA ploidi yanında proliferasyon aktivitesini yansıtan $\mathrm{S}$ fazının da ayrı bir prognostik faktör olduğu belirtilmektedir. Nitekim çalışmada, $S$ fazı $\% 6$ 'dan az olan tüm hastaların 5 yıl yaşadığ gözlenirken, $\mathrm{S}$ fazı \%10'un üzerinde olanların sadece \%10'u 5 yıl yaşayabilmiştir. Üstelik S fazının belirleyiciliğinin tümör evresinden bağımsız olduğu belirtilerek, DNA ploidisi yanında $\mathrm{S}$ fazının da prognostik bir faktör olduğu kabul edilmektedir.

Hakama (9) ise çalışmasında, Filderman'ın sonucu ile uyumluluk içerisinde, DNA ploididen ayrı olarak tümörün proliferasyon aktivitesini yansıtan $\mathrm{S}$ fazının da özellikle düşük evreli skuamöz cell akciğer kanserlerinde tek başına prognoz belirleyici bir parametre olduğunu belirtmektedir. Aynı araştırıcı bir başka çalışmasında akciğer kanseri tanısı alan olguları semptomatik ve asemptomatik diye 2 gruba ayırarak, her 2 grubun ploidi ve $\mathrm{S}$ fazlarını tespit etmiş ve asemptomatik grupta, diploid ve $\mathrm{S}$ fazı düşük olan olguların diğerlerine yaşam süresi bakımından belirgin üstünlük sağladığını gözlemiştir. Hakama'ya göre asemptomatik halde iken tesadüfen tespit edilen ve akciğer kanseri tanıs1 alan lezyonların, diploid ve $\mathrm{S}$ fazının düşük olması halinde bunları biyolojik açıdan tembel ve düşük malignite potansiyeli 
olan tümörler olarak değerlendirmek mümkündür (10).

Çalışmamızdaki olguların $\mathrm{S}$ fazı ortalaması $(\% 6,38)$, Volm'un çalışmasında belirtilen değerler ile uyumludur. Ancak takip dönemi içinde nüks veya metastaz görülen olgular incelendiğinde, postoperatif 5. ayda intrakranial metastaz ile en erken metastaz saptanan olgunun, diploid olmasına rağmen $\mathrm{S}$ fazının \%18 olarak belirlenmesi oldukça dikkat çekmektedir. Yine nüks veya metastaz görülen olguların, S fazı ortalamasının \% 7,06 olarak, tüm serinin $\mathrm{S}$ fazı ortalamasindan $(\% 6,38)$ yüksek bulunması, $S$ fazı ile prognoz arasındaki ilişkiyi göstermektedir. Böylece KHDAK'lerinde, $\mathrm{S}$ fazının prognostik bir faktör olarak kabul edilmesi görüşüne çalışmamız da destek vermektedir.

KHDAK'lerinde günümüze kadar yapılan çalışmalar ve elde edilen sonuçlardan sonra DNA ploidinin hangi histolojik tip ve evre için daha değerli olduğu konusunda hala tam bir fikir birliğine varılamamıştır. Rice ve Bauer (14) adlı araştırıcılar, oldukça geniş bir seri ile yaptıkları prospektif bir çalışmada, taze tümör dokusundan flow sitometri ile DNA ploidi analizi yapmışlar ve çalışma sonucunda özellikle skuamöz cell akciğer kanserlerinde tümör evresi ile DNA ploidi tipi ve DNA indeksini prognoz açısından çok değerli birer belirleyici olarak kabul etmişlerdir.

Yine buna benzer olarak Ayşegül Şahin (16) ile Isobe (11) ve Miyomato (12) adlı araştırmacılar çalışmalarında, DNA ploidinin özellikle skuamöz hücreli akciğer kanserleri için bağımsız bir prognoz belirleyici faktör olduğunu bildirmişlerdir.

Tanaka (17) ise, evre I akciğger adenokarsinomlu olguları ortalama 7,8 y1llık bir takip döneminden sonra DNA ploidi yönünden inceleyip, yaşam süresi ve nüks yönünden analizini yaptığında, anöploid olguların, diploid olanlara göre ilk 3 yıl içinde nüks açısından, ilk 5-6 yıl içinde de yaşam süresi açısından belirgin şekilde dezavantajlı olduğunu tespit etmiştir. Ayrıca bu çalışmada olguların hem parafin hem de taze doku örnekleri ile elde edilen sonuçların birbirine çok yakın olduğu gözlenerek, uzun zamandır süregelen parafin ve taze doku örneği arasında, hangisinin daha güvenilir olduğuna yönelik tartışmalara da açıklık getirilmiştir. Tanaka, çalışmanın sonunda DNA ploidinin, özellikle evre I akciğer adenokarsinomlarında yaşam süresi ve nüks açısından çok önemli bir kriter olduğunu ileri sürmüştür.

Moran ve Melamed (13) de yaptıkları çalışmada, DNA ploidinin, düşük evredeki akciğer adenokarsinomlarında prognoz için önemli olduğunu diğer histolojik tipler de ise prognoz ile herhangi bir ilişki belirlenemediğini belirtmişlerdir.

Evre I akciğer adenokarsinomlarında DNA ploidinin prognoz için en değerli belirleyici olduğunu ileri süren bu çalışmalara en çok karşı çıkan Cibas (4) olmuştur. Cibas, histolojik tanisı ve evresi patolojik olarak da onaylanan 93 adet evre I akciğer adenokarsinomlu olguya, DNA ploidi ve yaşam süresi analizi yaptığında anöploid ile diploid olgular arasında fark bulunmadığını saptayarak, DNA ploidinin evre I akciğer adenokarsinomlarında, prognostik bir faktör olarak kabul edilmemesi gerektiğini bildirmiştir.

Çalışmamızdaki anöploid olguların histolojik tip açısından analizi yapıldığında, 24 yassı hücre karsinomlu olgudan 9'unda (\%37,5) anöploidi saptanırken, 11 adenokarsinomlu olgudan 7'sinde $(63,6)$ anöploidi saptanmıştır. Görüldüğü gibi çalışma serimizdeki anöploidi sıklığı adenokarsinomlu olgularda yassı hücre karsinomlu olgulara göre daha fazladır. Bu sonuç başta Moran, Melamed ve Tanaka'nın sonuçları olmak üzere literatürdeki birçok çalışma sonucu ile uyumlu görünmektedir.

Schmidt (15) ise, T1N0 KHDAK'lerinde, flow sitometri ile nüks riskini karşılaştıran bir çalışma yapmış ve ploidi anormalliğinin prognoz açısından önemli olduğunu ancak ploidi anormalliği ve $S$ fazının, nüks riskini belirleme açısından değersiz bulunduğunu belirtmiştir. 
DNA ploidi üzerine son zamanlarda yapılan çalışmalardan Takeshita'nın (22) çalışmasında ise KHDAK'lerinde Aurora grubu üyesi ve mitoz düzenleyici anahtar rolünde bir protein olan Aurora B ile anöploidi ve kötü prognoz arasında belirgin bir ilişki olduğu bildirilmiştir. Yine akciğer kanserlerinde bronkoskopi ile alınan biyopsi örneğinde de sitometrik DNA analizi yapılarak klinik seyir hakkında tahmin yürütülebilir (23).

Çalışma serimizdeki toplam 11 adenokarsinomlu olgudan 7 'sinde $(\% 63,6)$ anöploidi saptanmış ve bunların da 4'ünde (\%57) nüks veya metastaz tespit edilmiştir. Bu sonuçlara göre anöploidi sıklığı ile anöploid olgulardaki nüks veya metastaz oranının adenokarsinomlarda, yass1 hücreli karsinomlardan daha fazla olduğu görülmektedir. Çalışmamızda elde edilen bu sonuçlar başta Schmidt (15) olmak üzere bazı araştırıcılar tarafindan öne sürülen anöploidinin, nüks veya metastaz belirlemede yetersiz olduğu düşüncesi ile uyumlu değildir.

Çalışmamızın olgu takip süresinin, literatürde bildirilen birçok çalışmaya göre kısa olmas1 ve son kontrolde normal olarak tespit edilen anöploid ve diploid olguların daha uzun süreli takipdeki durumlarının belirsizliği, çalışmamızın eksik yönleri olarak değerlendirilmiştir.

Sonuç olarak; KHDAK'lerinde, tümör hücresinin DNA ploidi tipi ve $\mathrm{S}$ fazı, prognostik önemi olan faktörlerdir. Flow sitometri, bu faktörlerin analizi için güvenilir ve pratik bir yöntem olarak değerlendirilmiştir. Özellikle anöploid DNA'lı ve belirgin S fazı yüksekliği olan akciğer kanserli olgular, sistematik olarak klinik ve radyolojik yönden mutlaka taranmalıdır.

Tablo 4: DNA ploidi tipi ile evre ve histopatolojik tiplerin sonuç açısından karşılaştırılması

\begin{tabular}{|c|c|c|c|}
\hline $\begin{array}{c}\text { EVRE-HISTOLOJIK } \\
\text { TIP }\end{array}$ & DNA TİPI & SURE & SONUÇ \\
\hline Evre ll. Adenoca. & Diploid & 5.ay & intrakranial metastaz \\
\hline Evre ll. Adenoca. & Anöploid & 12. ay & nüks \\
\hline Evre Illa. Adenoca & Anöploid & 12. ay & nüks \\
\hline Evre Illb. Adenoca & Anöploid & 13 ,ay & kemik metastazı \\
\hline Evre Illb. Adenoca & Anöploid & 16. ay & karş1 akciğerde metastaz \\
\hline Evre ll. Yassı h.li Ca. & Anöploid & 10.ay & kemik metastazı \\
\hline Evre ll. Yassı h.li Ca. & Anöploid & 13.ay & \\
\hline
\end{tabular}

Tablo 5: Histopatolojik tiplere göre anöploidi sıklı̆̆ı ile nüks veya metastaz görülme oranları

\begin{tabular}{|c|c|c|}
\cline { 2 - 3 } \multicolumn{1}{c|}{} & ANÖPLOİDİ & NÜKS VEYA METASTAZ \\
\hline Yassı hücreli ca.(n:24) & $9(\% 37,5)$ & $2(\% 22,2)$ \\
\hline Adenokarsinom(n:11) & $7(\% 63,6)$ & $4(\% 57)$ \\
\hline
\end{tabular}

\section{REFERANSLAR}

1. Bunn P,A., Camey D,N., Gazdar A,F., MatthewsM,J.:Diagnostic and biological implications of flow cytometric DNA content analysis in lung cancer. Cancer.1983;43:502632.
2. Carey A, F., Lamb D., Bird C, C.: Importance of sampling method in DNA analysis of lung cancer. J.Clin. Pathol.1990;43:820-23.

3. Carp Z, N., Ellison D,D., Brophy F,P., Watts P., Chang M.: DNA content incorrelation 
withpost surgical stage in NSCLC. Ann.ThoracSurg.1992;53:680-3.

4. Cibas S, E., Melamed R,M., Zaman B,M., KimmelM.: The effect of tumor size and tumor cell DNA content on the survival of patients with stage I adenocarcinoma of the lung. Cancer.1989;63: 1552-56.

5. Danesi T,D., Teodori L., Mauro F., MedınıC., Bott1C.: Prognostic significance of flow cytometry in Lung Cancer. Cancer.1987;60:844-51.

6. FildermanE, A., Silvestri A,G., Gatsonis C., Daniel J,L.: Prognostic significance of tumor proliferative fraction and DNA content in stage I NSCLC. American Rev.Respir. Dis.1992; 146:707-10.

7. Gönüllü U.:Akciğer kanserlerinin epidemiyolojisi ve etiyolojisi. Türkiye Klinikleri Tıp Bilimleri Dergisi.1995; 15:36165.

8. Granone P., Cardillo G., Rumi E., D'ugo D., Rumi C.: DNA FCM analysis in patients with operable non-small cell lung carcinoma. Eur. J. Cardiothorac Surg.1993;7:351-55.

9. Hakama M., Visakorpi T.: High cell proliferation activity determined by DNA Flow cytometry and prognosis in epidermoid lung carcinoma. ActaOncologica.1995;34:605-609.

10. Hakama M., Holli K., Visakorpi T., Pekola M., KallioniemiO.: Low biological aggresiveness of screen detected lung cancers may indicate overdiagnosis. lnt.J.Cancer.1996;66:6-10.

11. lsobe H.,Miyamato H., Shimizu T., Haneda H., Hashimoto M.: Prognostic and therapeutic significance of flow cytometric nuclear DNA content in NSCLC. Cancer.1990;65: 1391-95.

12. lsobe H.,Miyamato H., lnoue K., Shimizu M.: Flow cytometric DNA content analysis in primary lung cancer: Comparison of results from fresh and paraffin-embedded specimens. J. Surg. Onc. 1990;43:36-39.

13. Moran R,E., Melamed M,R.: Flow cytometric analysis of human lung cancer: Correlation With histologic type and stage. Anal. Quant. Cytol.1984;6:99-104.
14. Rice W,T., Bauer W, T., Gephardt G., Medendorp V,S., KirbyJ,T.:Prognostic significance of flow cytometry in NSCLC. J.Thorac CardiovascSurg1993;106:210-7.

15. Schmidt A,R., RuschW,V.,Piantadosi S.: A flow cytometric study of NSCLC classified as T1N0. Cancer.1992;69:78-85.

16. Şahin A,A., Ro Y,J., EI-Naggar K,A., Lee S,J., AyalaA.: Flow cytometric analysis of the DNA content of NSCLC. Cancer.1990;65:530-7.

17. Tanaka I., Masuda R., Furuhata Y., Inoue M., Fujiwara M.: Flow cytometric analysis of the DNA content of adenocarcinoma of the lung, especially for patients with stage I disease with long term followup. Cancer.1995;75:2461-65.

18. Ten Velde G,P,M., Schutte B., Vermeulen A., Blijham G.: Flow cytometric analysis of DNA ploidy level in paraffin-embedded tissue of NSCLC. Eur. J. Cancer. 1988;24:455-60.

19. Volm M., Mattem J., Sonka J., Sehaden V,M.: DNA distribution in non small cell lung carcinomas and relationship to clinical behavior. Cytometry .1985;6:348-56.

20. Zimmerman V,P., Hawson T,G., Bint H,M., Parsons G,P.: Ploidy as a prognostic determinant in surgically treated lung cancer.Lancet.1987;2:530-33.

21. Hedley D., Friedlander M,L., Taylor I,W.: Method for analysis of celluler DNA content of paraffin-embedded pathological material using FCM. J.Histochem. 1983;31:1333-38

22. Takeshita M., Koga T., Takayama K, Ijichi K., Yano T., Maehara Y., Nakanishi Y., Sueishi K.: Aurora-B overexpression is correlated with aneuploidy and poor prognosis in non-small cell lung cancer. LungCancer. 2013;80:85-90.

23. Oliani C., Barana D., Cazzadori A., Zanolin E., Santo A.,Pasini F., Padovani M., Mazzini G.,Cetto L.G : Cytofluorimetric evaluation of DNA ploidy in lung cancer: A bronchoscopic study. The International Journal of Biological Markers. 2005; 20(2): 87-92. 